\title{
Potent cytotoxic effects of Calomeria amaranthoides on ovarian cancers
}

\author{
Caroline van Haaften ${ }^{1 *}$, Colin C Duke ${ }^{2}$, Arij M Weerheim ${ }^{3}$, Nico PM Smit ${ }^{4}$, Paul MM van Haard ${ }^{5}$, Firouz Darroudi ${ }^{6}$, \\ Baptist JMZ Trimbos ${ }^{1}$
}

\begin{abstract}
Background: Ovarian cancer remains the leading cause of death from gynaecological malignancy. More than 60\% of the patients are presenting the disease in stage III or IV. In spite of combination of chemotherapy and surgery the prognosis stays poor for therapy regimen.

Methods: The leaves of a plant endemic to Australia, Calomeria amaranthoides, were extracted and then fractionated by column chromatography. In vitro cytotoxicity tests were performed with fractions of the plant extract and later with an isolated compound on ovarian cancer cell lines, as well as normal fibroblasts at concentrations of $1-100 \mu \mathrm{g} / \mathrm{mL}$ (crude extract) and $1-10 \mu \mathrm{g} / \mathrm{mL}$ (compound). Cytotoxicity was measured after 24, 48 and 72 hours by using a non-fluorescent substrate, Alamar blue.

In vivo cytotoxicity was tested on ascites, developed in the abdomen of nude mice after inoculation with human $\mathrm{OVCAR}_{3}$ cells intraperitoneally. The rate of change in abdomen size for the mice was determined by linear regression and statistically evaluated for significance by the unpaired t test.
\end{abstract}

Results: Two compounds were isolated by chromatographic fractionation and identified by ${ }^{1} \mathrm{H}-\mathrm{NMR},{ }^{13} \mathrm{C}-\mathrm{NMR}$ and mass spectrometry analyses, EPD, an $\alpha$-methylene sesquiterpene lactone of the eremophilanolide subtype, and EPA, an $\alpha$-methylene carboxylic acid.

Cytotoxicity of EPD for normal fibroblasts at all time points $I C_{50}$ was greater than $10 \mu \mathrm{g} / \mathrm{mL}$, whereas, for OVCAR cells at 48 hours $I C_{50}$ was $5.3 \mu \mathrm{g} / \mathrm{mL}$ (95\% confidence interval 4.3 to $6.5 \mu \mathrm{g} / \mathrm{mL}$ ).

Both, the crude plant extract as well as EPD killed the cancer cells at a final concentration of $10 \mu \mathrm{g} / \mathrm{mL}$ and $5 \mu \mathrm{g} /$ $\mathrm{mL}$ respectively, while in normal cells only $20 \%$ cell killing effect was observed. EPA had no cytotoxic effects. Changes in abdomen size for control versus Cisplatin treated mice were significantly different, $P=0.023$, as were control versus EPD treated mice, $P=0.025$, whereas, EPD versus Cisplatin treated mice were not significantly different, $P=0.13$.

Conclusions: For the first time both crude plant extract from Calomeria amaranthoides and EPD have been shown to have potent anti-cancer effects against ovarian cancer.

\section{Background}

Calomeria amaranthoides, described both by Ventenat and Smith in 1804 [1,2] as Humea elegans belonging to the genus Haeckeria in the tribe of Inuleae was grown in France and England from seeds originating from the Blue Mountains, New South Wales (NSW) in Australia. The plant is of a monotypic genus, endemic to NSW and Victoria, Australia [3].

\footnotetext{
* Correspondence: carocell@planet.nl

'Department of Gynaecology, Leiden University Medical Center, The Netherlands

Full list of author information is available at the end of the article
}

In 2004 the genus Haeckeria was reassessed by Orchard as C. amaranthoides and since then $C$. amaranthoides belongs to the genus Calomeria of the family Asteraceae (Compositae) [4]. As a biennial plant it can grow to more than three metres high, with flowers as waving plume bushes and wrinkly leaves with an aromatic scent. It is also called incense plant.

The plant family of Asteraceae are known for their natural products. One type includes sesquiterpene lactones (SL) which to date is of great interest for their potential as anti-cancer agents as reviewed by Heinrich et al. and Zhang et al. [5,6].

\section{Biomed Central}


Ovarian cancer is the fifth leading cause of death in women and remains the leading cause of death from gynaecological malignancy in many countries, in spite of chemotherapy with Platinum derivates and/or Taxol after surgery. Of the malignant epithelial tumors (>90\% of all ovarian cancers), the serous papillary variants form the largest subgroup $[7,8]$. Due to its dismal prognosis there is an urgent need for new treatment strategy for ovarian cancer.

For the first time we have studied $C$. amaranthoides for its possible anti-tumor activity. An SL (EPD) and a structurally related sesquiterpene (EPA) have been found, extracted and purified. Among them EPD has shown in vitro and in vivo (mice) high toxicity in ovarian cancers.

\section{Methods}

A voucher specimen of Calomeria amaranthoides, collected near Old Bell's Line of Road, Mount Tomah NSW 2758, Australia, is held in the John Ray Herbarium, University of Sydney, Collection number: Silvester 110118-01.

Leaves of $C$. amaranthoides, gathered in the Blue Mountains (Mount Tomah, NSW, Australia) were airdried while protected from sunlight.

\section{Fractionation of extracts by column chromatography}

Dried plant material (350 g), cut in small pieces was soaked in chloroform $\left(\mathrm{CHCl}_{3}\right)$ at room temperature. After 24-48 hours a crude extract of the leaves was removed and evaporated under reduced pressure $(21.3$ grams, 6.0\%). The residue, re-dissolved in $\mathrm{CHCl}_{3}$ (30 $\mathrm{mL})$ was applied to a column $(21 \mathrm{~cm} \times 5 \mathrm{~cm}$ i.d. $)$ filled with Silicagel (Lichroprep Si 60, particle size 15-25 $\mu$ m; Merck, Germany). Elution was carried out with a stepwise gradient consisting of hexane:dioxane, 98:2 (v/v $400 \mathrm{~mL}$ ); hexane:chloroform:dioxane, 88:10:2 (v/v 600 $\mathrm{mL})$; hexane:chloroform:dioxane:ethyl acetate:2-propanol, 80:10:2:6:1, (v/v $600 \mathrm{~mL}$ ) and hexane:chloroform: acetone:methanol, 56:20:16:8, (v/v $400 \mathrm{~mL})$. A total of 157 fractions (10 mL each) were collected and combined into groups based on HPLC analysis. The combined group of fractions showing the highest toxicity towards ovarian cancer cells was further fractionated by short column vacuum chromatography.

\section{High-performance liquid chromatography (HPLC)}

HPLC analyses were carried out using the Akta purifier (Amersham Pharmacia Biotech, Sweden) with a HPLCcolumn (150 mm × $4.6 \mathrm{~mm}$ i.d. plus pre-column; Grace, The Netherlands), filled with HS Silica (particle size $3 \mu \mathrm{m}$ ), UV detection at $214 \mathrm{~nm}, 254 \mathrm{~nm}$ and $280 \mathrm{~nm}$. Ten $\mu \mathrm{L}$ of the fractionated extract was injected, after dilution to $100 \mu \mathrm{L}$ with eluent $\mathrm{A}$ : hexane $(99.5 \mathrm{~mL})$ - dioxane $(0.5 \mathrm{~mL})$. The first 10 minutes the column was eluted at a flow rate of $0.5 \mathrm{~mL} / \mathrm{min}$ with eluent $\mathrm{A}$, followed by 30 minutes with eluent $\mathrm{B}$ : hexane $(85 \mathrm{~mL})$ diethyl ether $(10 \mathrm{~mL})$-ethanol $(5 \mathrm{~mL})$.

\section{${ }^{1} \mathrm{H}-\mathrm{NMR}$ and ${ }^{13} \mathrm{C}$-NMR analyses}

${ }^{1} \mathrm{H}-\mathrm{NMR}$ and ${ }^{13} \mathrm{C}$-NMR spectroscopy was performed on those plant fractions with clear cytotoxicity effects. ${ }^{1} \mathrm{H}$ NMR, ${ }^{13}$ C-NMR and Correlation Spectroscopy (COSY) were performed using a Varian Gemini $300 \mathrm{MHz}$ instrument (Palo Alto, CA, USA). The spectra were measured in parts per million ( $\mathrm{ppm}$ ) and were referenced to tetramethylsilane (TMS $=0 \mathrm{ppm})$.

Electrospray ionisation in positive and negative mode (ESI) mass spectrometry analyses were performed using a TSQ 7000 Liquid Chromatography Mass Spectrometer (LC-MS/MS; Thermo, San Jose, CA, USA), equipped with Xcalibur data acquisition and processing software. Short-Column Vacuum Chromatography (SCVC) was performed using a column packed with TLC-grade silica gel H60 (Merck, Darmstadt, Germany)) and applying a step-wise gradient of solvents with increasing polarity. Substances were detected by TLC performed on silica gel coated TLC plates (H60 F254, Merck, Germany) and by ${ }^{1} \mathrm{H}-\mathrm{NMR}$ spectroscopy. Structures of purified compounds were determined by mass spectrometry and ${ }^{1} \mathrm{H}-\mathrm{NMR}$ and ${ }^{13} \mathrm{C}$-NMR spectroscopy.

\section{Graphs and Statistics}

Graphing and statistical evaluations were carried out with GraphPad Prism 5 for Windows.

\section{Cell lines and cell cultures}

Cells used in the assays were five ovarian cell lines (JV, JG, JC, JoN, NF), which were earlier established $[9,10]$, two cell lines $\mathrm{OVCAR}_{3}$ and $\mathrm{SKOV}_{3}$ from the American Type Culture Collection (ATCC) as well as epithelial cells from the ovary (serous papillary cystadenomas) [11] and human dermal fibroblasts primary cultures [12].

\section{In vitro cytotoxicity tests with different fractions of $C$. amaranthoides}

In vitro cytotoxicity tests were performed using a nonfluorescent substrate, Alamar blue (BioSource Invitrogen, UK), as described by Pagé et al. [13]. Ovary cells $\left(1 \times 10^{4}\right.$ or $\left.5 \times 10^{4}\right)$ were seeded in 24 -wells plates (Costar, USA) and grown in RPMI-1640, supplemented with $6 \mathrm{mM} \mathrm{L}$-glutamine, 10\% fetal calf serum (FCS) (Gibco, Invitrogen, UK) and penicillin (100 units $/ \mathrm{mL}$ ) and streptomycin $(100 \mu \mathrm{g} / \mathrm{mL})$, while normal fibroblasts were grown in Dulbecco's modified Eagle medium (DMEM), also supplemented with L-glutamine and FCS. The cultures were maintained in a humidified atmosphere of $5 \% \mathrm{CO}_{2}$ at $37^{\circ} \mathrm{C}$. 
Cell cultures, in triplicates, in exponential growth were treated with the different dried fractions of the plant extract, redissolved in dimethyl sulfoxide (DMSO) and added at final concentrations of 1,10 and $100 \mu \mathrm{g} / \mathrm{mL}$. The control cultures had $0.02 \%(1 \mu \mathrm{g} / \mathrm{mL}) \quad 0.2 \%(10 \mu \mathrm{g} /$ $\mathrm{mL})$ and $2 \%(100 \mu \mathrm{g} / \mathrm{mL})$ DMSO added to the medium. In $2 \mathrm{~mL}$ medium/well 10\% Alamar blue was added and $100 \mu \mathrm{l}$ of the supernatants of the 24-well plates after 24, 48 and $72 \mathrm{hrs}$ incubations were pipetted into 96-well plates (Costar, USA). Cell viability was measured with a 96-well plate reader (Molecular Devices Ltd, UK). In a later stage, after identifying fractions with high cytotoxic effects, the final concentrations of extracts tested ranged from $1-10 \mu \mathrm{g} / \mathrm{mL}$, with final concentrations of 0.02 up to $0.2 \%$ DMSO.

\section{In vivo pilot experiment}

An in vivo pilot experiment was performed with 20 BALB/c nude mice (Charles River Laboratories, France). In order to mimic advanced ovarian cancer the mice were injected intraperitoneally (i.p.) with $10^{7} \mathrm{OVCAR}_{3}$ cells (ATCC) into the abdominal cavity to form ascites. Three groups of mice were examined: 6 control mice (no treatment), 6 mice treated with Cisplatin and 6 mice treated with EPD after ascites had formed. Cells of ascites of two mice were frozen and stored for future experiments. To study reduction of the swollen abdomen $5 \mathrm{mg} / \mathrm{kg}$ Platosin (Cisplatin, Pharma Chemie, The Netherlands) and the isolated compound EPD at a final concentration of $20 \mathrm{mg} / \mathrm{kg}$ were administered i.p.

\section{Results}

Fractionation of extracts by column chromatography

In total 157 fractions were sampled and, based on HPLC analyses, divided into four groups of combined fractions (fractions: 1-6, 60-70, 90-100 and 120-130) and then tested in vitro against ovarian cancer cell lines and normal cells. Group 2 (fractions: 60-70) showed the strongest cytotoxicity, killing all ovarian cancer cells at $10 \mu \mathrm{g} /$ $\mathrm{mL}$ but not at $1 \mu \mathrm{g} / \mathrm{mL}$. Other fractions did not show significant activities. This second group of fractions 60-70 (1.30 g, 0.37\% yield from crude extract) was further fractionated by normal-phase short-column vacuum chromatography on silica gel $\mathrm{H}$ (column dimensions $18 \mathrm{~mm} \times 65 \mathrm{~mm}$ i.d.), eluted with stepwise solvent gradients of hexane: dichloromethane, $1: 1 \mathrm{v} / \mathrm{v}(100 \mathrm{~mL}$ and $50 \mathrm{~mL})$; dichloromethane $(2 \times 50 \mathrm{~mL})$; dichloromethane: ethyl acetate, $4: 1 \mathrm{v} / \mathrm{v}(2 \times 50 \mathrm{~mL})$; dichloromethane: ethyl acetate, $1: 1 \mathrm{v} / \mathrm{v}(2 \times 50 \mathrm{~mL})$; ethyl acetate $(2 \times 50 \mathrm{~mL})$. From each fraction (12 in total) solvent was evaporated under reduced pressure and the residue was weighed.

Bioassays with ovarian cancer cells indicated fraction 4 (309 $\mathrm{mg}, 0.09 \%$ of the dried plant; out of the twelve fractions, see above) as the fraction with most of the cytotoxicity and its main chemical constituent was identified as EPD. A second main non-cytotoxic constituent, present mostly in Fractions 7 to 9 was identified as EPA (137 mg, 91\% purity by NMR and MS analyses).

Again, fractionation was applied to fraction 4 (enriched in EPD) using normal-phase short-column vacuum chromatography (silica gel $\mathrm{H}$; column dimensions $18 \mathrm{~mm} \times 65 \mathrm{~mm}$ i.d.), eluting with stepwise solvent gradients of hexane:dichloromethane, $2: 1 \mathrm{v} / \mathrm{v}(100$ $\mathrm{mL})$; hexane: dichloromethane, $1: 1 \mathrm{v} / \mathrm{v}(2 \times 50 \mathrm{~mL})$; hexane:dichloromethane, $1: 2 \mathrm{v} / \mathrm{v}(2 \times 50 \mathrm{~mL})$; dichloromethane $(2 \times 50 \mathrm{~mL})$; dichloromethane: ethyl acetate 4:1 $(2 \times 50 \mathrm{~mL})$; dichloromethane: ethyl acetate, $1: 1 \mathrm{v} / \mathrm{v}$ $(2 \times 50 \mathrm{~mL})$ to give the main chemical constituent, identified as an SL, EPD (93 mg, 90\% purity by NMR and MS analyses) and containing lipids and waxes (10\% by NMR analyses).

A small sample of freshly dried leaves (1.63 g) was extracted with dichloromethane $(100 \mathrm{~mL})$, filtered and the dichloromethane removed under reduced pressure leaving a dark green residue (62.6 mg, yield 3.9\%). Quantitative ${ }^{1} \mathrm{H}$-NMR analysis of a $\mathrm{CDCl}_{3}$ solution showed EPD 44\%, EPA $31 \%$ and a complex mixture of unidentified constituents $25 \%$.

A small sample of dried leaves (10.31 g), that had been stored in the dark under ambient conditions for 3.5 years was extracted with $\mathrm{CHCl}_{3}$ (100 mL, 48 hours) filtered and the $\mathrm{CHCl}_{3}$ removed under reduced pressure leaving a dark green-brown residue (0.62 g, yield 6.0\%). Quantitative ${ }^{1} \mathrm{H}$-NMR analysis of a $\mathrm{CDCl}_{3}$ solution showed that EPD and EPA were almost completely absent and a very complex mixture of unidentified constituents made up the bulk of the material.

\section{${ }^{1} \mathrm{H}-\mathrm{NMR}$ and ${ }^{13} \mathrm{C}-\mathrm{NMR}$ analyses \\ Eremophila-1(10)-11(13)-dien-12,8 $\beta$-olide (EPD)}

(3a $\alpha, 4 \mathrm{a} \alpha, 5 \alpha, 9 \mathrm{a} \alpha)-3 \mathrm{a}, 4,4 \mathrm{a}, 5,6,7,9,9 \mathrm{a}$-octahydro-4a,5dimethyl-3-methylenenaphtho[2,3-b]furan-2(3H)-2-one

$\mathrm{C}_{15} \mathrm{H}_{20} \mathrm{O}_{2}$ colourless liquid; ${ }^{1} \mathrm{H}-\mathrm{NMR}\left(\mathrm{CDCl}_{3}\right): \delta 0.92$ (s, H-14), 0.93 (d, J4,15 = $6.8 \mathrm{~Hz}, \mathrm{H}-15), 1.50$ (m, H-3), 1.60 (m, H-4), 1.70 (m, H-6), 2.03 (m, H-2), 2.30 (m, H9), $2.58\left(\mathrm{dd}, J_{9,9^{\prime}}=12.6 \mathrm{~Hz}, J_{8,9^{\prime}}=7.7 \mathrm{~Hz}, \mathrm{H}-9^{\prime}\right), 2.92(\mathrm{~m}$, $\mathrm{H}-7), 4.53\left(\mathrm{dt}, J_{7,8}=9.6 \mathrm{~Hz}, J_{8,9}=7.4 \mathrm{~Hz}, \mathrm{H}-8\right), 5.48(\mathrm{br}$ t, $\left.J_{1,2}=3.4 \mathrm{~Hz}, \mathrm{H}-1\right), 5.59\left(\mathrm{~d}, J_{13,13^{\prime}}=2.2 \mathrm{~Hz}, \mathrm{H}-13^{\prime}\right)$, $6.23\left(\mathrm{~d}, J_{13,13},=2.2 \mathrm{~Hz}, \mathrm{H}-13\right) ;{ }^{13} \mathrm{C}-\mathrm{NMR}\left(\mathrm{CDCl}_{3}\right)$ : $\delta 16.08,20.59,25.03,26.72$, 34.69, 34.91, 36.63, 37.01, $38.73,79.00,121.82,124.57,138.32,139.36,170.65$. Positive ion ESI-MS $[\mathrm{M}+\mathrm{Na}]^{+} 255(100),[\mathrm{M}+\mathrm{H}]^{+} 233(65)$. Xanthanodien or EPD is an $\alpha$-methylene SL [14].

Eremophila-1(10),11(13)-dien-12-oic acid (EPA)

$\mathrm{C}_{15} \mathrm{H}_{22} \mathrm{O}_{2}$ colourless liquid; ${ }^{1} \mathrm{H}-\mathrm{NMR}\left(\mathrm{CDCl}_{3}\right): \delta 0.85(\mathrm{~d}$, $\left.J_{4,15}=6.4 \mathrm{~Hz}, \mathrm{H}-15\right), 0.91$ (s, H-14), 1.45 (m, H-6), 1.50 (m, H-4), 1.55 (m, H-3), 1.60 (m, H-8), 1.85 (m, H-9), 
2.01 (m, H-2), 2.40 (m, H-9'), 2.55 (m, H-7), 5.38 (br t, $J_{1,2}=3.4 \mathrm{~Hz}, \mathrm{H}-1$ ), 5.66 (br s, H-13'), 6.29 (br s, H-13); ${ }^{13} \mathrm{C}-\mathrm{NMR}\left(\mathrm{CDCl}_{3}\right): \delta 16.08,20.59,25.03,26.72,34.69$, $34.91,36.63,37.01,38.73,79.00,121.82,124.57,138.32$, 139.36, 170.65. Negative ion ESI-MS [M-H] 233 (100)

EPA, is an $\alpha$-methylene carboxylic acid [15].

The remaining impurities in the purified sample of EPD and EPA (Figures $1 \mathrm{~A}$ and $1 \mathrm{~B}$ ) were identified as waxes and lipids. No other sesquiterpenoid substances of similar structure to EPD and EPA were detected.

\section{In vitro cytotoxicity tests}

Cell viability of normal skin fibroblasts and of cells of the ovarian cell line JC treated with the crude plant extract for 24, 48 and 72 hours at final concentrations of 1,10 and $100 \mu \mathrm{g} / \mathrm{mL}$ was as follows:

The screening test for the fibroblasts with doses of 1 , 10 and $100 \mu \mathrm{g} / \mathrm{mL}$ measured for $1 \mu \mathrm{g} / \mathrm{mL}$ : after 24 hours showed cell viability of 104\%; after 48 hours $97 \%$; and after 72 hours 98\%; for $10 \mu \mathrm{g} / \mathrm{ml}$ : after 24 hours cell viability showed 100\%; after 48 hours $96 \%$; and after 72 hours $80 \%$; and for $100 \mu \mathrm{g} / \mathrm{mL}$ : after 24 hours cell viability showed 98\%; after 48 hours $83 \%$; and after 72 hours $65 \%$. At all time points $\left(24,48\right.$ and 72 hours) $\mathrm{IC}_{50}$ was greater than $100 \mu \mathrm{g} / \mathrm{mL}$.

The screening test for the JC cells with doses of 1,10 and $100 \mu \mathrm{g} / \mathrm{mL}$ measured for $1 \mu \mathrm{g} / \mathrm{mL}$ : after 24 hours showed cell viability of $98 \%$; after 48 hours $97 \%$; and after 72 hours $70 \%$; for $10 \mu \mathrm{g} / \mathrm{mL}$ : after 24 hours cell viability showed $85 \%$; after 48 hours $84 \%$; and after 72 hours $21 \%$; for $100 \mu \mathrm{g} / \mathrm{mL}$ : after 24 hours cell viability showed 77\%; after 48 hours $84 \%$; and after 72 hours $8 \%$. At the time points 24 and 48 hours $\mathrm{IC}_{50}$ was greater than $100 \mu \mathrm{g} / \mathrm{mL}$ and at 72 hours $\mathrm{IC}_{50}$ was $2.5 \mu \mathrm{g} / \mathrm{mL}$ (95\% confidence interval (C.I.) 0.22 to $28 \mu \mathrm{g} / \mathrm{mL}$ ).

A similar type of biological assay was performed with the purified compound EPD at final concentrations of 1 , 5 and $10 \mu \mathrm{g} / \mathrm{mL}$ for 24,48 and 72 hours (Table 1). Percent of cell reduction for normal fibroblasts at 72 hours at the highest dose $(10 \mu \mathrm{g} / \mathrm{mL})$ was approximately $30 \%$, while IC 50 was greater than $10 \mu \mathrm{g} / \mathrm{mL}$. Screening tests
Table 1 Cell viability with EPD treatment of normal fibroblasts, $\mathrm{OVCAR}_{3}$ and $\mathrm{SKOV}_{3}$ cancer cells (average (AV) and standard deviation (SD))

\begin{tabular}{|c|c|c|c|c|c|c|}
\hline \multirow{3}{*}{$\begin{array}{r}\text { EPD Conc } \\
\mu \mathrm{g} / \mathrm{mL}\end{array}$} & \multicolumn{6}{|c|}{$\%$ cell viability: average and standard deviation } \\
\hline & \multicolumn{2}{|c|}{24 hours } & \multicolumn{2}{|c|}{48 hours } & \multicolumn{2}{|c|}{72 hours } \\
\hline & AV & SD & AV & SD & AV & SD \\
\hline & \multicolumn{6}{|c|}{ Normal fibroblasts } \\
\hline 1 & 102 & 2.5 & 107 & 3.9 & 105 & 3.3 \\
\hline 5 & 105 & 6.3 & 108 & 1.6 & 72 & 2.1 \\
\hline \multirow[t]{2}{*}{10} & 101 & 10.1 & 112 & 1.8 & 47 & 4.6 \\
\hline & \multicolumn{6}{|c|}{$\mathrm{OVCAR}_{3}$} \\
\hline 1 & 96 & 5.1 & 101 & 7.4 & 109 & 29.2 \\
\hline 5 & 87 & 6.7 & 67 & 4.5 & 50 & 14.4 \\
\hline \multirow[t]{2}{*}{10} & 70 & 7.4 & 23 & 0.9 & 21 & 6.4 \\
\hline & \multicolumn{6}{|c|}{$\mathrm{SKOV}_{3}$} \\
\hline 1 & 103 & 5.0 & 123 & 8.2 & 119 & 6.0 \\
\hline 5 & 102 & 4.0 & 96 & 18.2 & 69 & 16.5 \\
\hline 10 & 86 & 11.6 & 31 & 36.0 & 23 & 1.8 \\
\hline
\end{tabular}

$\mathrm{IC}_{50}$ for $\mathrm{OVCAR}_{3}$ at 24 hours was $13 \mu \mathrm{g} / \mathrm{mL}(95 \%$ C.I. 10 to $18 \mu \mathrm{g} / \mathrm{mL})$, at 48 hours $6.4 \mu \mathrm{g} / \mathrm{mL}$ (95\% C.I. 5.3 to $7.8 \mu \mathrm{g} / \mathrm{mL}$ ) and at 72 hours $5.3 \mu \mathrm{g} / \mathrm{mL}(95 \%$ C.I. 4.3 to $6.5 \mu \mathrm{g} / \mathrm{mL}$ ).

$\mathrm{IC}_{50}$ for $\mathrm{SKOV}_{3}$ at 24 hours was $16 \mu \mathrm{g} / \mathrm{mL}$ (95\% C.I. 9.4 to $27 \mu \mathrm{g} / \mathrm{mL}$ ), at 48 hours $8.4 \mu \mathrm{g} / \mathrm{mL}$ (95\% C.I. 6.7 to $11 \mu \mathrm{g} / \mathrm{mL}$ ) and at 72 hours $6.5 \mu \mathrm{g} / \mathrm{mL}(95 \%$ C.I. 5.2 to $8.3 \mu \mathrm{g} / \mathrm{mL}$ ).

for $\mathrm{OVCAR}_{3}$ and $\mathrm{SKOV}_{3}$ cells showed that more than $50 \%$ and $80 \%$ of cells were killed at doses of 5 and $10 \mu \mathrm{g} / \mathrm{mL}$, respectively.

\section{In vivo pilot experiment}

Control mice only injected with the $\mathrm{OVCAR}_{3}$ cells, were killed when the ascites became a burden. EPD (at final concentration of $20 \mathrm{mg} / \mathrm{kg}$ b.w.) was administered i.p. twice/week for six weeks and Cisplatin (at final concentration of $5 \mathrm{mg} / \mathrm{kg}$ b.w.) was administered i.p. during 4 weeks, once/week. In general a similar cytotoxic effect was observed between EPD and Cisplatin on the $\mathrm{OVCAR}_{3}$ cells. However, mice treated with EPD could be kept for a much longer period of time than those mice treated with Cisplatin, for the latter the mice had lost weight significantly and had to be sacrificed after the fourth week. Moreover, following EPD treatment for

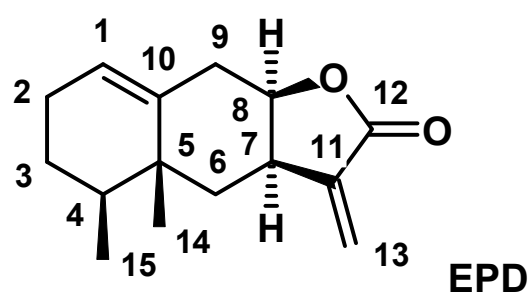

A

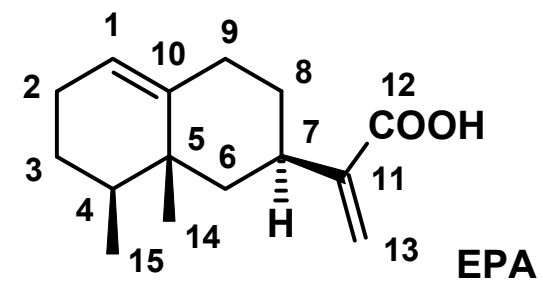

B

Figure 1 Chemical structures. A. Chemical structure of an $\alpha$-methylene sesquiterpene lactone, EPD. B. Chemical structure of an $\alpha$-methylene carboxylic acid, EPA. 
6 weeks, three mice were kept alive for another month to see if the reduced abdomen would stay of normal size. Two mice kept their normal size abdomen, whereas, after 6 weeks the abdomen of the third mouse started to increase in size (Table 2).

The rate of change in abdomen size for the mice was determined by linear regression (Figure 2) and statistically evaluated for significance by the unpaired $t$ test. Control versus Cisplatin treated mice were significantly different, $\mathrm{P}=0.023$, as were control versus EPD treated mice, $\mathrm{P}=0.025$, whereas, $\mathrm{EPD}$ versus Cisplatin treated mice were not significantly different, $\mathrm{P}=0.13$.

\section{Discussion}

The chemical constituents composition of aerial parts of C. amaranthoides have been examined once before by Zdero et al. [16]. None of the constituents reported by them were identified in the C. amaranthoides described in this study. The three constituents reported [16] are isomeric with the two major constituents reported in this study, EDP and EPA. The different constituents reported previously may be due to incomplete isolation and analyses or possibly the result of variation in constituent profiles of plant phenotypes. Another possible explanation is degradation on storage. Our studies have shown that freshly dried plant material is necessary as dried plant material stored for over three years was found to yield less than one-tenth of the normal yield of EDP and EPA.

For the first time the anti-cancer activity of $C$. amaranthoides has been examined. Two major sesquiterpenes with the eremophilanolide structure sub-type were

Table 2 Average abdomen size and standard deviation of $B A L B / c$ nude mice

\begin{tabular}{rcccccc}
\hline \multicolumn{6}{c}{ Average abdomen size and standard deviation (cm) } \\
\multicolumn{6}{c}{ Control } & \multicolumn{2}{c}{ cisplatin } & EPD & \\
Days & AV & SD & AV & SD & AV & SD \\
\hline 1 & 2.1 & 0.173 & 2.567 & 0.115 & 2.333 & 0.115 \\
7 & & & & & 2.4 & 0.173 \\
8 & 2.333 & 0.153 & 2.525 & 0.33 & & \\
12 & & & & & 2.367 & 0.231 \\
14 & & & 2.5 & 0.258 & & \\
16 & 2.767 & 0.153 & & & & \\
19 & & & 2.475 & 0.222 & 2.267 & 0.058 \\
21 & 3 & 0.346 & 2.5 & 0.183 & & \\
26 & 3.1 & 0.141 & 2.1 & 0.1 & 1.967 & 0.208 \\
33 & & & & & 2 & 0 \\
36 & & & & & 2.267 & 0.058 \\
61 & & & & & 2.467 & 0.289 \\
63 & & & & & 2.533 & 0.321 \\
68 & & & & & & \\
\end{tabular}

identified by ${ }^{1} \mathrm{H}-\mathrm{NMR}$ and ${ }^{13} \mathrm{C}$-NMR and by mass spectrometry and by comparison with published ${ }^{1} \mathrm{H}-\mathrm{NMR}$ partial spectra as eremophila-1(10)-11(13)-dien-12,8 3 olide (EPD or Xanthanodien) and eremophila-1(10),11 (13)-dien-12-oic acid (EPA) [14,15]. Belonging to the family of Asteraceae, this family has contributed a large number of natural products including SL's. The alphamethylene gamma-lactone ring is responsible for their bioactivity. Various SL's have demonstrated their anticancer capability in in vitro cell culture and by prevention of metastasis in in vivo animal models [6]. Thus, it is not surprising that $C$. amaranthoides extract can kill cancer cells, given the fact that one of the two isolated sesquiterpenes, EPD, shows high toxicity.

In 1972 a diastereoisomer of EPD, $(3 a \beta, 4 a \alpha, 5 \alpha, 9 \alpha \beta)$ 3a,4,4a,5,6,7,9,9a octahydro4a,5-dimethyl-3-methylenenaphtho[2,3- $b]$ furan-2(3H)-2-one, has been described as "naphthofuranone" by the National Cancer Institute (NCI) in their "in vivo" anti-tumor screening data, testing the drug against P388 Leukemia in CD2F1 mice, however, no final conclusive results were reported [17]. An allergenic sesquiterpene lactone, Alantolactone, found in "Elfdock" Inula helenium has been shown to be toxic to leukocytes. Although with the same molecular weight and molecular formula as EPD it belongs to the eudesmanolide structure sub-type [18]. This SL has a different chemical structure from EPD, with different positions of one methyl and one double bond.

In the present study, EPA, the other sesquiterpene isolated and identified, did not show cytotoxic effects on the ovarian cancer at concentrations up to $10 \mu \mathrm{g} / \mathrm{mL}$ of purified compound.

Besides the cytotoxic effects of the crude extract of $C$. amaranthoides with clear effects at $10 \mu \mathrm{g} / \mathrm{mL}$ (cell reduction $>80 \%$ ), the isolated biologically active compound EPD has been shown to have high cytotoxicity $(>50 \%)$ for ovarian cancer cells at lower concentrations of $5 \mu \mathrm{g} / \mathrm{mL}$ (72 hours) and increased (> 60\%) with a dose of $10 \mu \mathrm{g} / \mathrm{mL}$ (at 48 hours; Table 1). Interestingly, both the crude plant extract and EPD did show only a slight cytotoxic effect (20\%-30\%) on normal fibroblasts in vitro at a concentration of $10 \mu \mathrm{g} / \mathrm{mL}$ (at 72 hours). The in vivo pilot experiment with $\mathrm{BALB} / \mathrm{c}$ nude mice (Table 2, Figure 2) did show that both EPD and Cisplatin reduced the size of the abdomen. The difference, however, was that mice treated with Cisplatin were in poor condition and became wasted compared with the EPD treated mice.

Ovarian cancer has a poor prognosis. With more than $60 \%$ of the patients presenting the disease in stage III or IV, combination chemotherapy with Platinum and Taxol after cytoreductive surgery gives the most tolerated standard regimen $[19,20]$. 


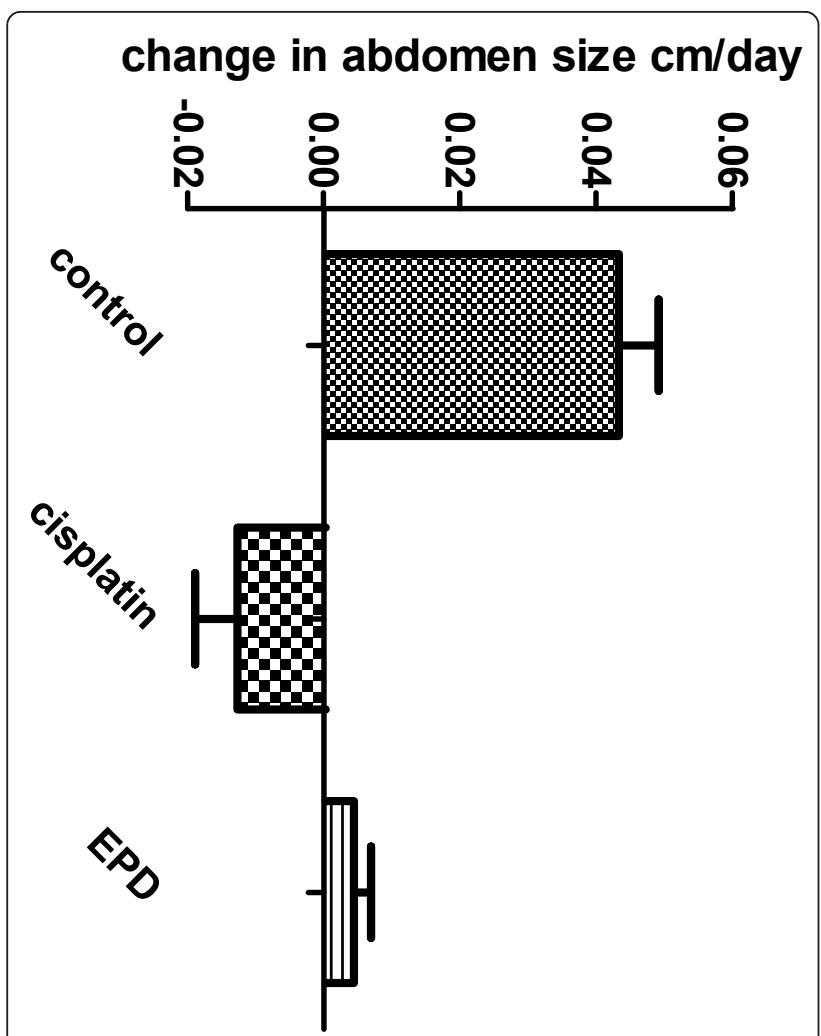

Figure 2 Changes in abdomen size for control and treated mice.

In spite of the introduction of new drugs into the management of ovarian cancer there is still need for more novel treatments.

\section{Conclusion}

The compound EPD has shown unique cytotoxicity effects on both in vitro (ovarian cancer cell lines) as well as in vivo (mice). Interestingly, it had low cytotoxic effects on normal cells.

More studies in vivo are required to verify the mechanisms and mode of action of EPD, and to further validate the potential of EPD as an anti-cancer drug in ovarian cancer and other types of cancer.

\section{Acknowledgements}

We thank Fred Romijn, Wouter Temmink (LUMC, Leiden) and Alma Edelman (RDGG, Delft) for their technical assistance.

A European patent was recently granted for the crude extract of Calomeria amaranthoides: EP 1843759

\section{Author details}

'Department of Gynaecology, Leiden University Medical Center, The Netherlands. ${ }^{2}$ Faculty of Pharmacy, University of Sydney, NSW 2006, Australia. ${ }^{3}$ Skin Research Laboratory, Leiden University Medical Center, Leiden, The Netherlands. ${ }^{4}$ Department of Clinical Chemistry, Leiden University Medical Center, Leiden, The Netherlands. ${ }^{5}$ Department of Clinical Chemistry, Medical Laboratories, Reinier de Graaf Group of Hospitals, Delft, The Netherlands. ${ }^{6}$ Department of Toxicogenetics, Leiden University, Medical Center Leiden, The Netherlands.

\section{Authors' contributions}

Data were extracted by $\mathrm{CVH}$ and CCD and analyzed by FD and NPMS. CCD and AWW contributed substantially to data acquisition and analysis. The paper was written by $\mathrm{CVH}$ and critically revised by FD and approved by all other authors including BJMZT. Revision of the manuscript was largely performed by $\mathrm{CVH}$ and $\mathrm{CCD}$. All authors have read and approved the final manuscript.

\section{Competing interests}

The authors declare that they have no competing interests.

Received: 16 November 2010 Accepted: 14 March 2011

Published: 14 March 2011

\section{References}

1. Ventenat EP: 'Jardin de la Malmaison'. De Crapelet and Orchard (Paris); 18041,2.

2. Smith JE: 'Exotic botany'. Taylor R \& Co. (London); 18041.

3. Puttock CF: Calomeria. In Flora of Victoria. Volume 4. Edited by: Walsh NG and Entwistle TJ. Melbourne, Inkata Press; 1993.

4. Orchard AE: A reassessment of the genus Haeckeria (Asteraceae: Gnaphalieae), with definition of new species in Cassinia. Australian Systematic Botany 2004, 17:447-449.

5. Heinrich M, Robles M, West JE, Ortiz de Montellano BR, Rodriguez E: Ethnopharmacology of Mexican Asteraceae (Compositae). Annual Reviews 1998, 38:539-565.

6. Zhang S, Won Y-K, Ong C-N, Shen H-M: Anti-Cancer potential of sesquiterpene lactones: Bioactivity and molecular mechanisms. Curr Med Chem-Anti-Cancer Agents 2005, 5:239-249.

7. Scully RE, Young RH, Clement PB: Tumors of the ovary, maldeveloped gonads, fallopian tube, and broad ligament. In Atlas of Tumor Pathology. Volume Third. Edited by: Scully RE, Young RH, Clement PB. Washington, DC, Armed Forces Institute of Pathology; 1998.

8. The Merck Manual of Diagnosis and Therapy, Gynecology And Obstetrics. Gynecol Neoplasms 2006, 241(18).

9. Van Haaften-Day C, Russell P, Rugg C, Wills EJ, Tattersall MHN: Flow cytometric and morphological studies of ovarian carcinoma cell lines and xenografts. Cancer Res 1983, 43:3725-3731.

10. Van Haaften-Day C, Russell P, Brammah-Carr S: Two homologous mixed Müllerian tumor lines of the ovary and their characteristics. Cancer 1990, 65:1753-1761.

11. Van Haaften-Day C, Russell P, Davies S, Brammah-Carr S: An in vitro study of ovarian atypical proliferating (borderline) serous tumors. Int J Gynecol Cancer 1992, 2:41-48.

12. Brookes S, Rowe J, Ruas M, Llianos S: INK4a-deficient human diploid fibroblasts are resistant to RAS-induced senescence. The EMBO Journal 2002, 21:2936-2945.

13. Pagé $B$, Pagé $M$, Noel $C$ : A new fluorometric assay for cytotoxicity measurements in vitro. Int J Oncol 1993, 3:473-476.

14. Tanaka N, Yazawa T, Aoyama K, Murakami T: Chemische untersuchungen der inhaltsstoffe von Xanthium canadense Mill. Chem Pharm Bull 1976, 24:1419-1421.

15. Bohlmann F, Zdero C, Silva M: Two further eremophilane derivatives from Tessaria absynthioides. Phytochem 1977, 16:1302-1303.

16. Zdero C, Bohlmann F, Anderberg A, King RM: Eremophilane derivates and other constituents from Haeckeria species and further Australian Inuleae. Phytochem 1991, 30:2643-2650.

17. NCl: In Vivo Antitumor Screening Data. Cancer Chemotherapy Reports 1973, 2:3.

18. Dupuis $\mathrm{G}$, Brisson J: Toxic effect of alantolactone and dihydroalantolactone in in vitro cultures of leukocytes. Chem Biol Interact 1976, 15:205-217.

19. Markman M: Optimizing primary chemotherapy in ovarian cancer. Hematol Oncol Clin N Am 2003, 17:957-968.

20. Bookman MA, Greer BE, Ozols RF: Optimal therapy of advanced ovarian cancer: carboplatin and placitaxel (GOG158) and an update on GOG0182-ICON5. Int J Gynecol Cancer 2003, 13:149-155.

doi:10.1186/1756-9966-30-29

Cite this article as: van Haaften et al: Potent cytotoxic effects of Calomeria amaranthoides on ovarian cancers. Journal of Experimental \& Clinical Cancer Research 2011 30:29. 